\title{
Improvement of Raw Milk Cheese Hygiene through the Selection of Starter and Non-Starter Lactic Acid Bacteria: The Successful Case of PDO Pecorino Siciliano Cheese
}

\author{
Raimondo Gaglio, Massimo Todaro (D) and Luca Settanni *(D) \\ Department of Agricultural, Food and Forestry Science, University of Palermo, Viale delle Scienze 4, \\ 90128 Palermo, Italy; raimondo.gaglio@unipa.it (R.G.); massimo.todaro@unipa.it (M.T.) \\ * Correspondence: luca.settanni@unipa.it
}

Citation: Gaglio, R.; Todaro, M.; Settanni, L. Improvement of Raw Milk Cheese Hygiene through the Selection of Starter and Non-Starter Lactic Acid Bacteria: The Successful Case of PDO Pecorino Siciliano Cheese. Int. J. Environ. Res. Public Health 2021, 18, 1834. https:// doi.org/10.3390/ijerph18041834

Academic Editors: Miguel Elias,

Maria João Fraqueza, Marta Laranjo and Luís Patarata

Received: 8 January 2021

Accepted: 10 February 2021

Published: 13 February 2021

Publisher's Note: MDPI stays neutral with regard to jurisdictional claims in published maps and institutional affiliations.

Copyright: (C) 2021 by the authors. Licensee MDPI, Basel, Switzerland. This article is an open access article distributed under the terms and conditions of the Creative Commons Attribution (CC BY) license (https:/ / creativecommons.org/licenses/by/ $4.0 /)$.
Abstract: This review article focuses on the technological aspects and microbiological critical points of pressed-cooked cheeses processed from raw ewe's milk without the inoculation of starter cultures, in particular "Pecorino" cheese typology produced in Italy. After showing the composition of the biofilms adhering to the surface of the traditional dairy equipment (mainly wooden vat used to collect milk) and the microbiological characteristics of PDO Pecorino Siciliano cheese manufactured throughout Sicily, this cheese is taken as a case study to develop a strategy to improve its hygienic and safety characteristics. Basically, the natural lactic acid bacterial populations of fresh and ripened cheeses were characterized to select an autochthonous starter and non-starter cultures to stabilize the microbial community of PDO Pecorino Siciliano cheese. These bacteria were applied at a small scale level to prove their in situ efficacy, and finally introduced within the consortium for protection and promotion of this cheese to disseminate their performances to all dairy factories. The innovation in PDO Pecorino Siciliano cheese production was proven to be respectful of the traditional protocol, the final cheeses preserved their typicality, and the general cheese safety was improved. An overview of the future research prospects is also reported.

Keywords: lactic acid bacteria; microbial variability; starter selection; traditional cheese; bacterial stabilization

\section{Introduction}

The origin of cheese is particularly ancient; it is dated back to 8000 years ago when this dairy fermented product was already produced in the Middle-East [1]. Italy is characterized by a long history of cheese production. In Sicily, which represents the largest island in the Mediterranean sea, the production of cheese began with the Phoenician community [2], and the discovery of several archaeological finds indicated that the dairy activity was routinely conducted in the island in the Eneolithic age [3].

Generally, all hard cheeses made from ewes' milk produced in Italy are referred to as "Pecorino" cheeses. The term Pecorino is an adjective that comes from "pecora," the Italian translation of ewe. The wider tradition of raw ewe's milk transformation is concentrated in the southern regions [4,5]. Indeed, Pecorino cheese is produced almost throughout Italy, with names strictly indicating the geographical origin like Pecorino Romano, Pecorino Siciliano, Pecorino Sardo, and Pecorino Toscano among the most known products [6]. All these cheeses are considered typical products since they are transformed by the application of traditional production processes in given geographical areas [7]. Most of them enjoy the "protected designation of origin" (PDO) status, a recognition of quality conferred by the European Community to protect some agricultural products and foodstuffs produced in a specific area and following their production protocols [8].

PDO Pecorino Siciliano cheese is produced from raw ewe's milk without the inoculation of starter cultures in milk using traditional wooden equipment. In these conditions, 
the microbiota responsible for the acidification of curd and maturation of cheese originates from the raw milk, the equipment, the animal rennet, and, in general, the transformation (dairy) environment $[9,10]$. The microorganisms necessary to transform milk into cheese are lactic acid bacteria (LAB): Those acting during the first hours/days of productions are starter species, which have to generate a high amount of lactic acid basically through the fermentation of lactose, while the species acting during ripening, important to develop the final organoleptic notes, are indicated as non-starter LAB [11]. Both groups of LAB contribute to controlling the development of undesired microorganisms, but their activities and the stressing physicochemical conditions of the mature cheeses, mainly represented by low $\mathrm{pH}$, high concentrations of organic acids, low water activity, and moderate sodium chloride content [12], might not be enough to eliminate the presence of spoilage and opportunistic pathogen microorganisms from Pecorino Siciliano cheese [6].

Todaro et al. [6] isolated and identified Citrobacter freundii and Stenotrophomonas maltophilia among the potential pathogenic bacteria and Pseudomonas putida within the spoilage agents at consistent levels, together with several non-starter LAB, in some PDO Pecorino Siciliano cheeses. This paper reviews the strategy planned, and the works performed to improve the hygienic and safety aspects of PDO Pecorino Siciliano cheese based on the isolation, characterization, and selection of starter and non-starter LAB, as well as their application at the laboratory, small scale, and large scale level.

\section{PDO Pecorino Siciliano Cheese Technology}

PDO Pecorino Siciliano is a semi-hard cheese produced following a century-old protocol from raw ewe's milk collected into wooden vats where it is transformed, adding animal rennet in a paste, dissolved into warm water before addition, without LAB starter inoculums. The production area of this PDO cheese is quite wide, because it is represented by the entire Sicily region (South Italy) with its $25,711 \mathrm{~km}^{2}$. The protocol of production was regulated in 1955 [13] making PDO Pecorino Siciliano cheese probably one of the oldest European cheeses whose production has been regulated [14]. PDO Pecorino Siciliano cheese is counted among the pressed-cooked cheeses [15], and the transformation process is graphically reported in Figure 1.

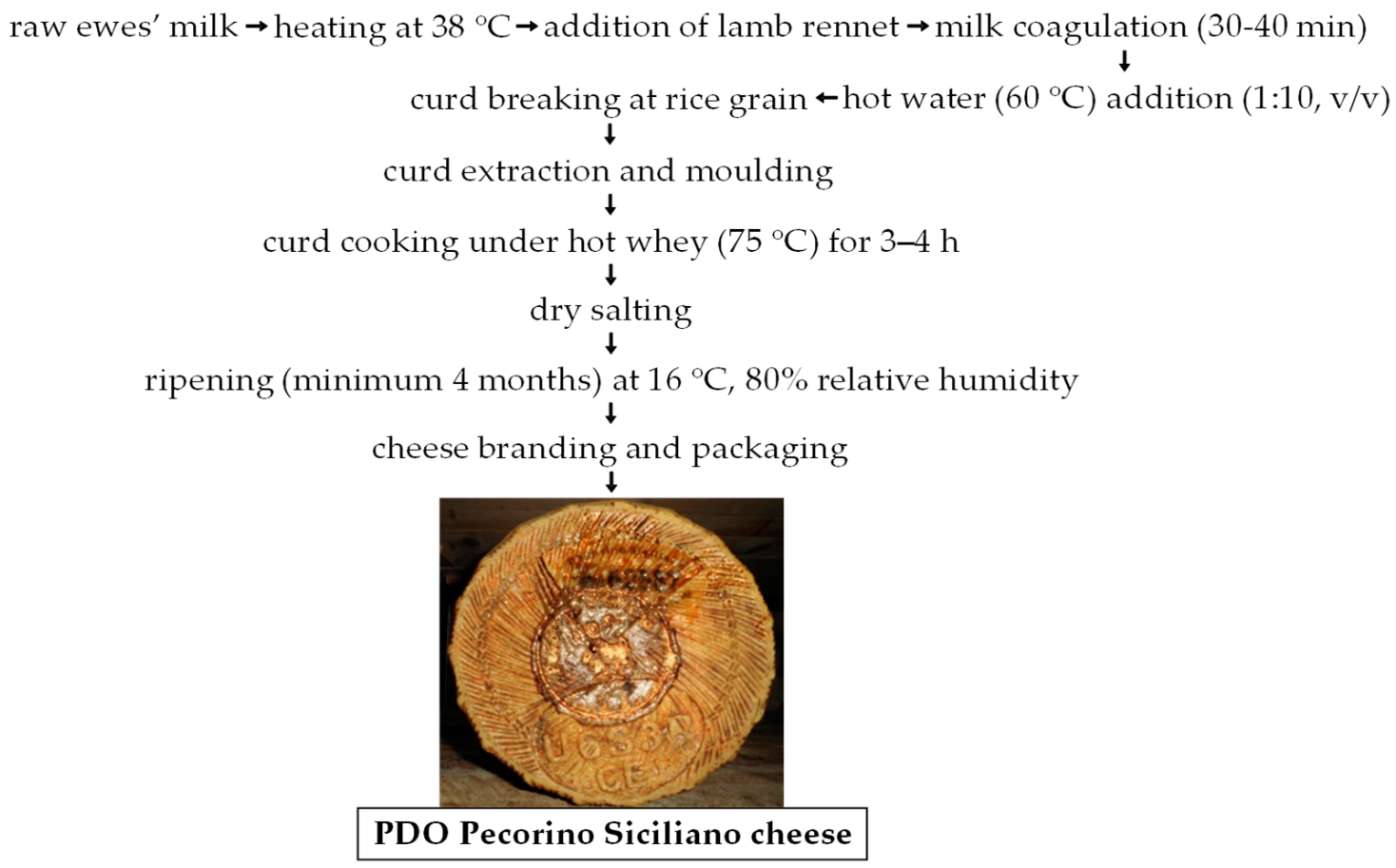

Figure 1. Main steps of protected designation of origin (PDO) Pecorino Siciliano cheese production. Adapted from Settanni et al. [16]. 
In particular, the milk is preheated at a temperature of $38{ }^{\circ} \mathrm{C}$, even though in the practice of the dairy factories, a temperature of $35-37^{\circ} \mathrm{C}$ is often registered. The curd is then broken by a wooden stick beater (called "rotula" in the local dialect) until reaching pieces of rice grain dimensions, and the curd is pressed into rattan baskets in order to facilitate the draining of the whey. These containers also provide the final shape to the cheeses, which are cooked under hot (about $75^{\circ} \mathrm{C}$ ) deproteinized whey, namely "scotta whey" (residual from Ricotta cheese production [17]) for about 3-4 h just after molding. Curdling and cooking are performed into the same wooden vat, called "tina" in the local dialect, where raw milk was collected. The traditional wooden equipment used for PDO Pecorino Siciliano cheese production is mainly made of chestnut or Douglas fir, genus Pseudotsuga, wood [18], even though recent attempts to introduce other local wood typologies of the Sicilian forestry resources showed interesting results during raw ewes' milk cheese production $[19,20]$.

\section{Role of the Wooden Vat during PDO Pecorino Siciliano Cheese Production}

The European Regulation (EC) no. 1935/2004 refers to the materials in contact with foods [21]. Basically, any material must not transfer its constituents to foods. Even though the measures regarding plastics, active and intelligent materials, epoxy derivatives, regenerated cellulose, and ceramics have been harmonized and adopted at the European level, there are no specific indications for wood as a food contact material. Thus, member countries legislate at different levels [22]. E.g., in France and Italy (mainly in the Sicily region), wooden equipment is used for dairy purposes thanks to the EC no. 2074/2005, which allows derogation from the EC no. 852/2004 for foods with traditional characteristics "as regards the type of materials of which the instruments and the equipment used specifically for the preparation, packaging, and wrapping of these products are made" [23].

Traditional Sicilian cheeses are in contact with wood during the entire production process, from milking until ripening. Figure 2 reports the main steps of production of PDO Pecorino Siciliano cheese, highlighting the constant contact with wooden equipment.

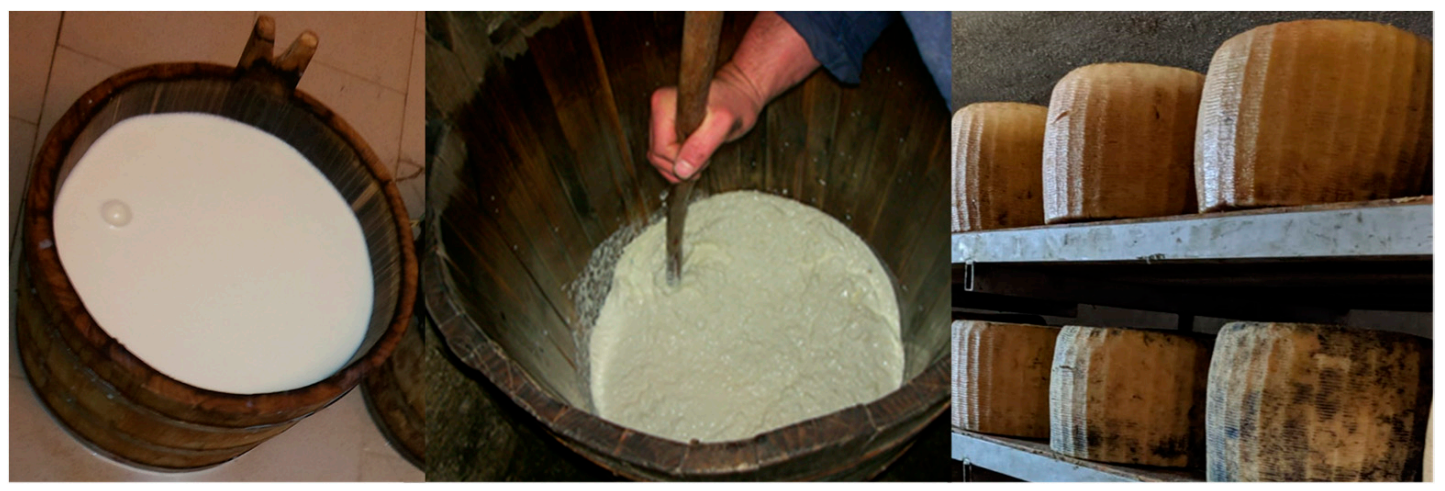

Figure 2. Contact of raw milk and ripened cheeses with wooden equipment during the production of PDO Pecorino Siciliano cheeses.

Among the wooden equipment generally used to produce the typical Sicilian cheeses, the vat used to collect the bulk milk for curdling assumes the most important microbiological role because it acts as a reservoir of starter LAB necessary to acidify the curd [18,24-26]. The wooden vat is also important to provide the non-starter LAB responsible for the desirable changes occurring during cheese ripening [27-29]. Both starter and non-starter LAB are transferred from the wooden vat to the milk during the first minutes of contact $[18,24,30]$ thanks to the biofilms formed on its internal surface $[19,31]$. A given biofilm is an aggregate of microorganisms embedded into their exopolysaccharides (EPS) adhering to a solid surface [32,33]. The ultrastructure of wood surfaces is porous (Figure 3a), facilitating the absorption and trapping of bacteria, which may develop a complex biofilm (Figure $3 \mathrm{~b}$ ). 


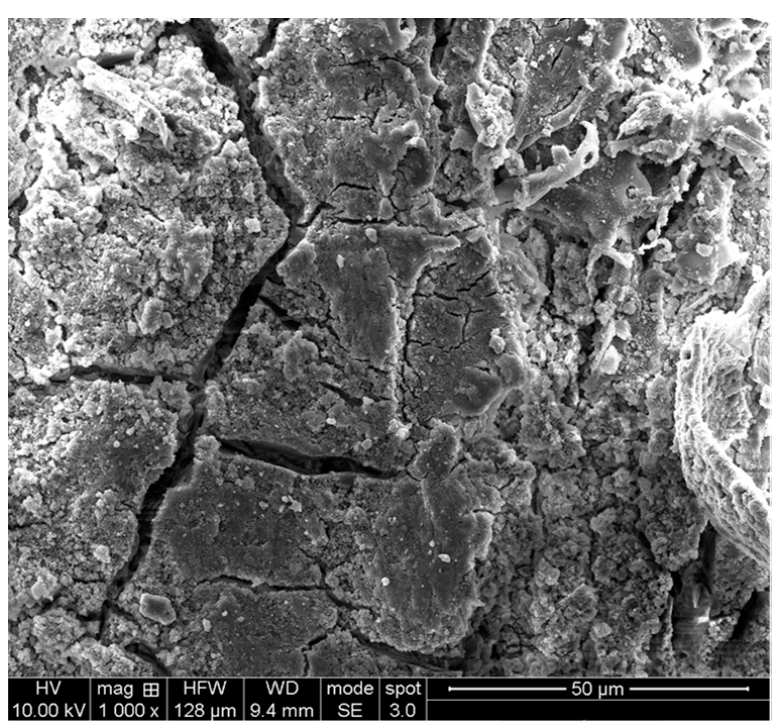

(a)

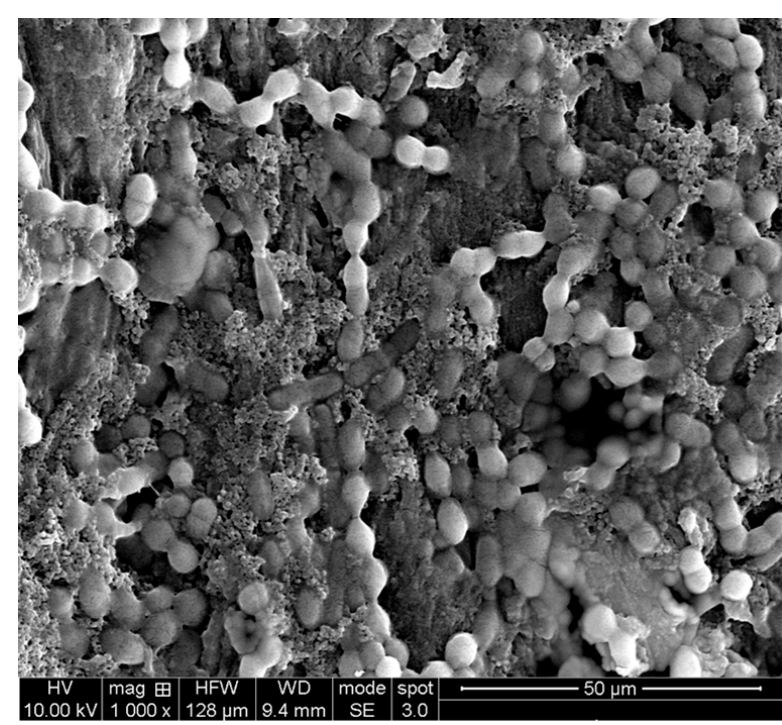

(b)

Figure 3. Scanning electron microscopy observations of wooden vat surface. (a) Before microbial activation; (b) after contact with scotta whey.

In order to allow the development of the desired LAB onto the internal surfaces of the wooden vats (early bacterial biofilm formation, Figure 4), the new vats, just after their construction, undergo the first treatment with hot water $\left(80{ }^{\circ} \mathrm{C}\right)$ for approximately 30 consecutive days (Figure 4a). This treatment is aimed at removing the tannin components. Subsequently, the internal surfaces of the vats are vigorously brushed with coarse salt (Figure 4b) and filled in with hot water once again to remove the salt. After this surface preparation protocol is applied, the biofilms formed through the daily contact with hot (approximately $70^{\circ} \mathrm{C}$ ) scotta whey (Figure 4c) for almost seven consecutive days [19].

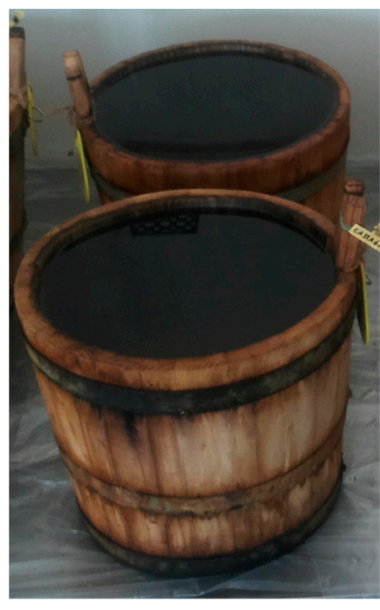

(a)

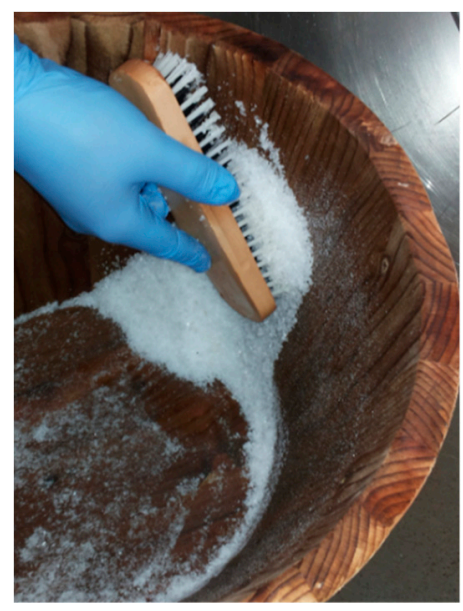

(b)

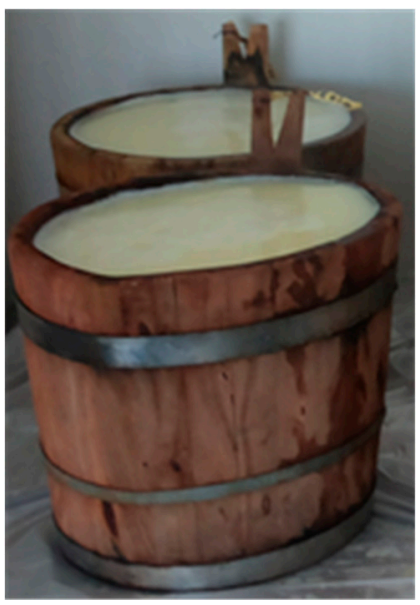

(c)

Figure 4. Bacterial activation of wooden vat surfaces with dairy lactic acid bacteria (LAB): (a) Tannin removal with hot water for 30 days; (b) coarse salt brushing; (c) Scotta whey contact for 7 days.

The wooden vat biofilms associated with the production of PDO Pecorino Siciliano cheeses are often the same used for the production of PDO Vastedda della valle del Belice cheese, which was thoroughly investigated by some authors [18,34]. To this purpose, it is important to note that most of LAB were identified as Lactobacillus, but since 2020 the nomenclature of lactobacilli underwent a consistent revision by Zheng et al. [35], and the bacteria previously grouped into the genus Lactobacillus are currently split into 23 different 
genera. However, in order to better understand the results of the research of Scatassa et al. $[18,34]$, as well as those of the other research objectives of this review article, LAB whose nomenclature was revised, will be reported with the current names and the old names between brackets at the first citation. The collection of the wooden vat biofilms occurred by the brushing technique reported by Didienne et al. [30]. Briefly, the vat surfaces were sampled, positioning UV-treated paper squares halfway on the bottom and up the side of the vat (Figure 5).

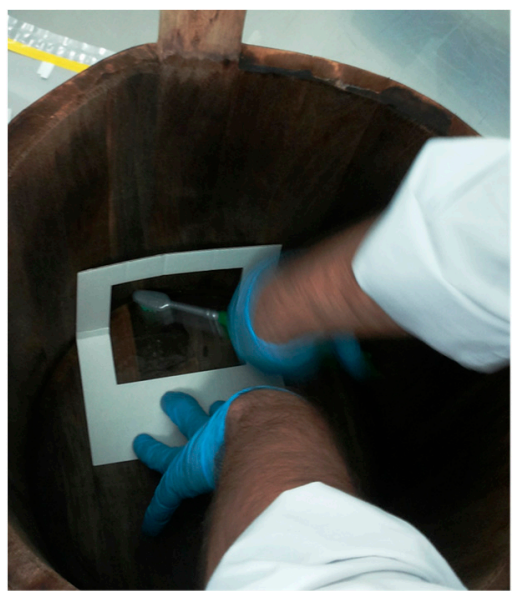

(a)

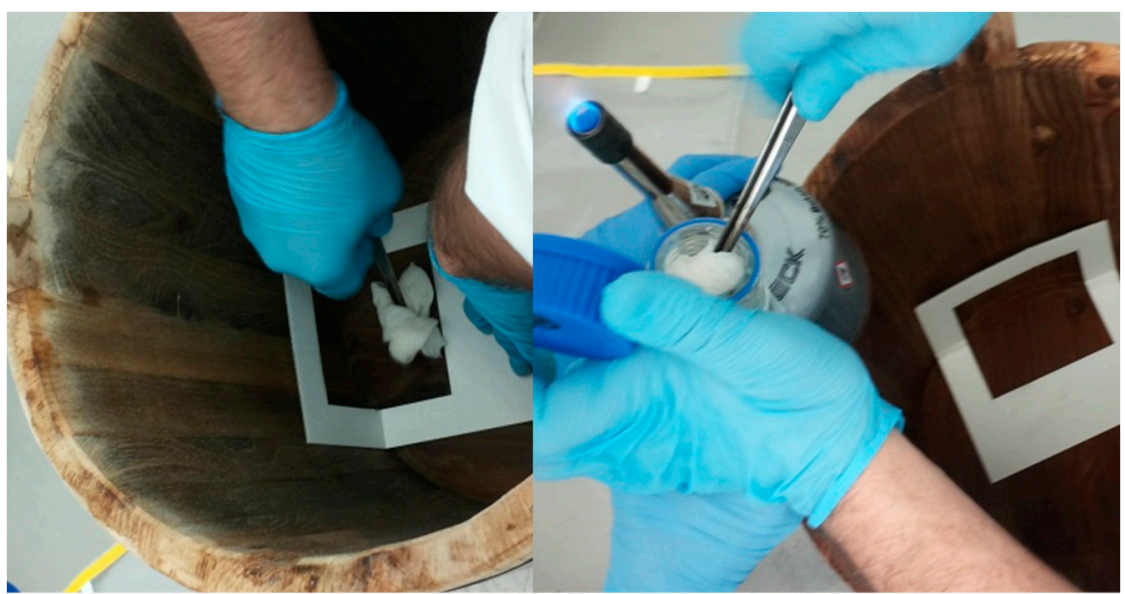

(b)

Figure 5. Wooden vat biofilm collection: (a) Brushing; (b) collection by gauze.

The biofilms were subjected to plate counts, and the colonies showing different morphological appearances were isolated, purified, and identified by $16 \mathrm{~S}$ rRNA gene sequencing as belonging to several LAB genera [18,34]. In particular, the species identified were: Enterococcus durans, Enterococcus faecium, Enterococcus faecalis, Enterococcus hirae, Streptococcus lutetiensis, Streptococcus gallolyticus subsp. macedonicus, Streptococcus thermophilus, Pediococcus acidilactici, Lactococcus lactis, Levilactobacillus brevis (formerly Lactobacillus brevis), Limosilactobacillus fermentum (formerly Lactobacillus fermentum), Lacticaseibacillus casei (formerly Lactobacillus casei), Lactobacillus delbrueckii, and Lacticaseibacillus rhamnosus (formerly Lactobacillus rhamnosus).

In light of the Commission Regulation (EC) No 2073/2005 [36], Scatassa et al. [18] also applied the microbiological criteria for foodstuffs to the wooden vats used to transform milk into cheese. To this purpose, the presence of Listeria monocytogenes and Salmonella spp. was investigated as food safety criteria, while that of Escherichia coli and coagulasepositive staphylococci as process hygiene criteria. The investigation results showed that $L s$. monocytogenes and Salmonella spp. were not detected, coagulase-positive staphylococci were below the detection limit, while Es. coli was found only in one vat out of the five objects of study. Some authors stated that the absence of these pathogenic species onto the surface of the wooden vats is due to their inability to adhere or to survive in the microbial biofilms for a combination of stress conditions such as the production of organic acids, the competition for nutrients, and the generation of antimicrobial compounds, mainly bacteriocins, by LAB and also to the high temperatures applied for cheese cooking [26,37]. To this purpose, Scatassa et al. $[18,34]$ tested all isolates through the general assays applied to evaluate the bacteriocin-like inhibitory substance production [38], finding that a consistent percentage of vat LAB inhibited some indicator strains, including Ls. monocytogenes (strain ATCC 19114). These results provided evidence that the wooden vat biofilms contribute actively to the microbial safety of the traditional cheeses. 


\section{Microbial Ecology of PDO Pecorino Siciliano Cheese}

Even though PDO Pecorino Siciliano cheese has been produced for centuries, the first documentation regarding the microbial ecology of similar Pecorino Siciliano cheeses was published in 2006 by Vernile et al. [39]. Those authors characterized only the levels of LAB in cheese produced in different seasons, showing that after three months of ripening, mesophilic rods and cocci were approximately at the same level, which was estimated at about $10^{7} \mathrm{cfu} / \mathrm{g}$. Two years later, the same authors [40] reported the genotypic characterization of those LAB showing that the species associated with the ripening of PDO Pecorino Siciliano cheese were E. faecium, E. faecalis, Lacticaseibacillus paracasei (formerly Lactobacillus paracasei), Lactiplantibacillus plantarum (formerly Lactobacillus plantarum), Lactiplantibacillus pentosus (formerly Lactobacillus pentosus), Lt. rhamnosus, Latilactobacillus curvatus (formerly Lactobacillus curvatus) and leuconostocs. Todaro et al. [6] evaluated the microbiological characteristics of PDO Pecorino Siciliano cheeses of different weights subjected to two different salting technologies (dry salting and a combined dry-brine salting). That work showed that $\mathrm{LAB}$ and the undesired spoilage and potentially pathogenic bacteria (pseudomonads and members of Enterobacteriaceae family) were almost at the same levels $\left(10^{5} \mathrm{cfu} / \mathrm{g}\right)$ after five months of ripening. LAB populations included E. durans, E. faecium, E. faecalis, Lactococcus garvieae, L. brevis, P. acidilactici, Pediococcus pentosaceus, S. gallolyticus subsp. macedonicus, and Streptococcus infantarius. Randazzo et al. [41] revealed the presence of Lc. lactis, S. thermophilus, Streptococcus bovis, E. faecalis, and Leuconostoc mesenteroides in artisanal Pecorino Siciliano cheeses through the application of a combined culture-dependent andindependent approach. Caggia et al. [42] specifically performed the isolation of non-starter LAB from Pecorino Siciliano cheeses in order to collect a group of LAB to be screened for probiotic features identifying several $L t$. rhamnosus and $L t$. paracasei.

The species associated with the wooden equipment and those identified in PDO Pecorino Siciliano cheeses included mesophilic (Lc. lactis) and thermophilic (S. thermophilus) starter LAB. In general, the thermophilic species are associated with the cheese core [43], where the temperature reached during cooking is maintained for a longer time than at the under rind [44]. However, the majority of the species identified from the wooden vats and ripened PDO Pecorino Siciliano cheeses were allotted into the non-starter LAB group. Among these, in the last years, S. gallolyticus subsp. macedonicus and Lc. garvieae represent adjunct cultures inoculated during different Italian cheese productions [45,46]. Enterococci are responsible for several typicality notes of cheese [47] but may carry antibiotic resistance genes and virulence factors [48]. These bacteria, besides being naturally present in raw milk [49,50] and in the wooden vat biofilms [18,34], have also been isolated from the animal rennet pastes used in traditional Sicilian cheese production [51], indicating that the presence of enterococci in the final cheeses might have different origins. Once their harmlessness is ascertained [48], enterococci can be selected as secondary adjunct cultures also for their contribution to extending cheese shelf life due to the bacteriocin production $[47,52]$. With the aim of investigating the antibiotic resistance distribution among Pecorino Siciliano cheese enterococci, Russo et al. [53] isolated several strains belonging to the species E. faecium. The authors detected a high resistance of the strains towards rifampicin, erythromycin, and ampicillin and also found that several strains exhibited multidrug-resistant phenotypes highlighting concerns regarding the spread of antibiotic resistance by dairy enterococci.

Todaro et al. [6] focused the attention on the isolation and identification of the undesirable bacteria of PDO Pecorino Siciliano cheeses, finding out that this community was composed of Pseudomonas putida, Pseudomonas vronovensis, C. freundii, Enterobacter spp., Es. coli, Klebsiella oxytoca, Serratia grimesii, and Sn. maltophilia. Although the presence of the potentially pathogenic bacteria Enterobacter spp., K. oxytoca, C. freundii, and Es. coli was documented for Italian raw milk Pecorino cheese typology during the first month of ripening [54], the surprising finding of the work of Todaro et al. [6] was that these species were still viable in cheeses ripened for five months. Members of Enterobacteriaceae family at high levels have also been reported for raw ewes' milk cheeses produced in Greece and Portugal $[55,56]$ and their main implication with human health is basically related to the 
production of biogenic amines [57]. A rapid decline of K. oxytoca detected in curd was reported during the ripening of Serra ewe's cheese [58], and this phenomenon is important to reduce the risk of hemorrhagic colitis caused by this bacterium [59]. Even though $C$. freundii is considered as a low virulence microorganism, it could be responsible for several infections, including pneumonia, diarrhea, and septicemia [60]. Escherichia coli is naturally present in the intestine of warm-blooded animals and represents an indicator of fecal contamination, but it is also implicated in gastrointestinal diseases [61].

Regarding spoilage bacteria, Pseudomonas spp. are generally isolated from raw ewes' milk cheeses with a limited ripening time [62]. Generally, pseudomonads are present at high cell densities when $\mathrm{pH}$ is high [63]; thus, a rapid $\mathrm{pH}$ drop is necessary to hamper their development. Fresh Pecorino Siciliano "primosale" cheeses, namely "primosale", were specifically investigated at a retail sale by Giammanco et al. [64] for the presence of Staphylococcus aureus and Es. coli finding out that a consistent percentage of the samples analyzed were positive for these two species. However, the study evidenced that those results depended on post-production contamination, in particular, the retail sale conditions may have played a key role in the development of St. aureus and Es. coli. Furthermore, Cardamone et al. [65] inoculated the four main dairy pathogenic species (Es. coli O157, Ls. monocytogenes, Salmonella Enteritidis, and St. aureus) at the production stage of Pecorino Siciliano cheese and evaluated their behavior during ripening. The results of the investigation indicated that PDO Pecorino Siciliano cheese production conditions determined a consistent decrease in the growth of all four bacteria inoculated.

PDO Pecorino Siciliano cheese was also specifically investigated for the presence of biogenic amines with the aim of correlating these compounds with cheese microbiology [66]. Indeed, biogenic amines are toxic compounds generated through the microbial decarboxylation of amino acids [67]. Only histamine was detected at a high concentration in PDO Pecorino Siciliano cheese. Guarcello et al. [68] selected some cheese LAB that did not carry amino acid decarboxylase genes and found that some of them even showed a biogenic amine degrading ability determining the selection of LAB starters useful to prevent the accumulation of these toxic compounds in experimental cheeses.

In light of the several microorganisms implicated in human pathogenicity and shelflife issues isolated from ripened Pecorino cheeses, the selection and application of starter strains are of paramount importance to obtain safe and stable cheeses.

\section{Improvement of PDO Pecorino Siciliano Cheese Hygiene through Selected LAB Addition}

Although the wooden vats used to produce PDO Pecorino Siciliano cheeses were proven to be safe systems for milk transformation, the presence of consistent numbers of spoilage/pathogenic bacteria in the final cheeses determined an alert on the entire production system of this PDO cheese. The sole wooden vat LAB biofilms are unable to sanitize the microbiological conditions of raw ewes' milk, which is often very close to the European limit $(<500,000 \mathrm{cfu} / \mathrm{mL})$ for the "good microbiological quality" of raw ewes" milk to be processed into cheese when it is not thermally treated [69]. Thus, a revision of the production protocol of PDO Pecorino Siciliano cheese based on the addition of selected autochthonous starter and non-starter LAB was suggested to improve the hygienic conditions of the final cheeses.

According to the classification of Mucchetti and Neviani [70], based on the treatment of milk and the type of selected starters added, the Italian cheeses can be produced from pasteurized milk inoculated with selected starters, pasteurized milk inoculated with natural starters, thermal treated milk inoculated with natural starters, raw milk inoculated with selected starters, raw milk inoculated with natural starters, and raw milk without starter addition. PDO Pecorino Siciliano cheese belongs to the last cheese typology, which deserves major microbiological attention due to the survival of the raw milk bacteria during cheese production [71], even though vat LAB exerts antagonistic measures [26,37]. From this perspective, PDO Pecorino Siciliano cheese represented a case study to convert the 
transformation process from raw milk without starters to a production performed with raw milk added with natural starters.

Settanni et al. [16] isolated potential starter LAB from acidified PDO Pecorino Siciliano curds, while non-starter LAB was collected from ripened cheeses [6]. Both LAB groups were selected for their main dairy traits: Starter $L A B$ determined the rapid acidification of UHT milk and showed rapid autolysis, while non-starter LAB was chosen for their opposite behavior since a low acidification capacity and slow autolysis are compatible with long ripening times [50]. Sixty-two curd LAB isolates were collected and tested for acidification and autolysis kinetics, but only two strains, both identified as Lc. lactis subsp. lactis, resulted in rapid acidifiers and highly autolytic. The secondary adjunct culture was composed of three strains (one strain per Lc. garvieae, E. faecalis and S. gallolyticus subsp. macedonicus), which were the weakest acidifiers and showed the slowest autolytic activity. These five cultures, individually or in starter/non-starter LAB combination, were applied to produce experimental cheeses in the dairy factory whose cheeses showed the highest levels of spoilage and potentially pathogenic bacteria by Todaro et al. [6]. The bulk milk was collected into the wooden vat daily used by the cheese-maker in order to enrich the milk with the vat biofilms. The entire milk volume was divided into seven aliquots and transferred into plastic vats. One vat was not inoculated with any exogenous LAB culture and represented the control trial, while six vats received $\mathrm{LAB}$ inoculums according to the experimental plan (Figure 6). The cheeses were produced applying the traditional PDO Pecorino Siciliano cheese-making protocol, and the ripening lasted five months.

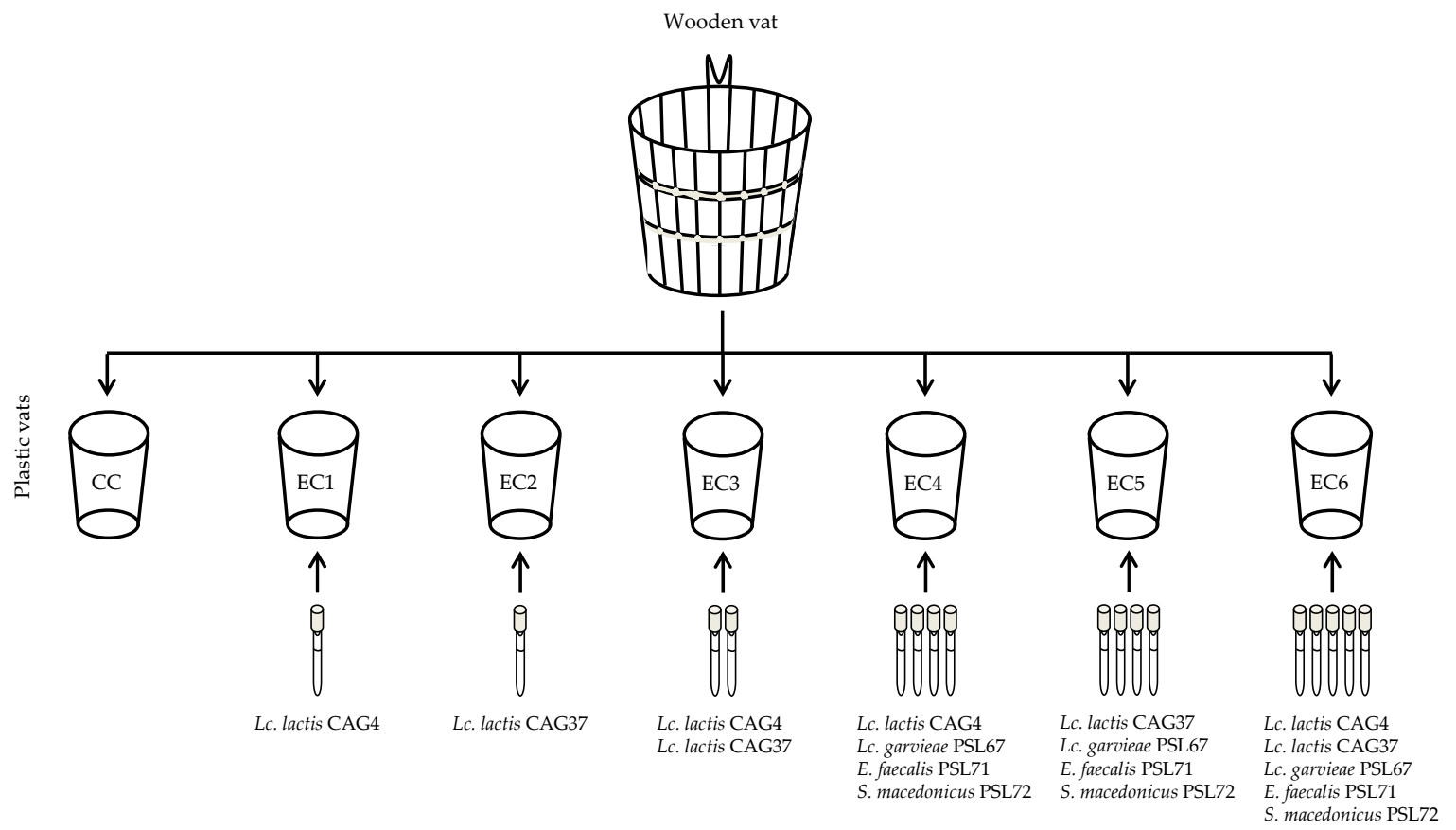

Figure 6. Experimental design of PDO Pecorino Siciliano cheese production performed at the factory-scale level. Adapted from Settanni et al. [16].

The experimental trials were first followed for their acidification kinetics by monitoring $\mathrm{pH}$ and microbiological levels. Both starter strains determined a similar $\mathrm{pH}$ decrease in the six inoculated trials, and their $\mathrm{pH}$ drop was faster than that registered for the control trial. After 7 days of acidification, the control cheeses showed higher levels of Pseudomonads spp. and members of Enterobacteriaceae family than cheeses produced with the starter/non-starter LAB inoculums. At the end of the ripening period, prolonged for five months to perform the direct comparison with the cheeses analyzed by Todaro et al. [6], both Pseudomonads spp. and members of Enterobacteriaceae family were below the detection limit in all inoculated cheeses, while their levels were $3.7 \mathrm{cfu} / \mathrm{g}(\log 10)$ in 
control cheeses. The species Lc. lactis subsp. lactis successfully reduced the presence of Enterobacteriaceae family members also when added as starter culture during the production of raw ewes' milk Portuguese Serra de Estrela cheese [72] and different traditional Serbian cheeses [73]. The addition of selected Lc. lactis subsp. lactis isolated from PDO Pecorino Siciliano curds in milk with microbiological levels close to the limits of the CE Regulation 853 [69] ameliorated the hygienic conditions of the final cheeses. Furthermore, the sensory analysis showed that the cheeses produced with the starter/non-starter LAB inoculums retained a typical sensory profile. Thus, the performances of the selected LAB needed to be tested at a large scale level considering other dairy factories within the consortium for the protection and promotion of PDO Pecorino Siciliano cheese.

\section{Microbial Stabilization of PDO Pecorino Siciliano Cheese Production}

The approach of Settanni et al. [16] was followed by Guarcello et al. [74] to extend the results of the selection of the mixed starter (Lc. lactis subsp. lactis)/non-starter (E. faecalis, Lc. garviae, S. gallolyticus subsp. macedonicus) LAB inoculum to six dairy factories located in different areas of Sicily (Figure 7) within five provinces (Agrigento, Catania, Enna, Palermo, and Trapani), all being part of the consortium for PDO Pecorino Siciliano cheese protection and promotion. The application of the selected LAB was performed in an attempt to stabilize the microbiological characteristics of PDO Pecorino Siciliano cheese, preserving its typicality, throughout the regional territory where the disciplinary allows the production.

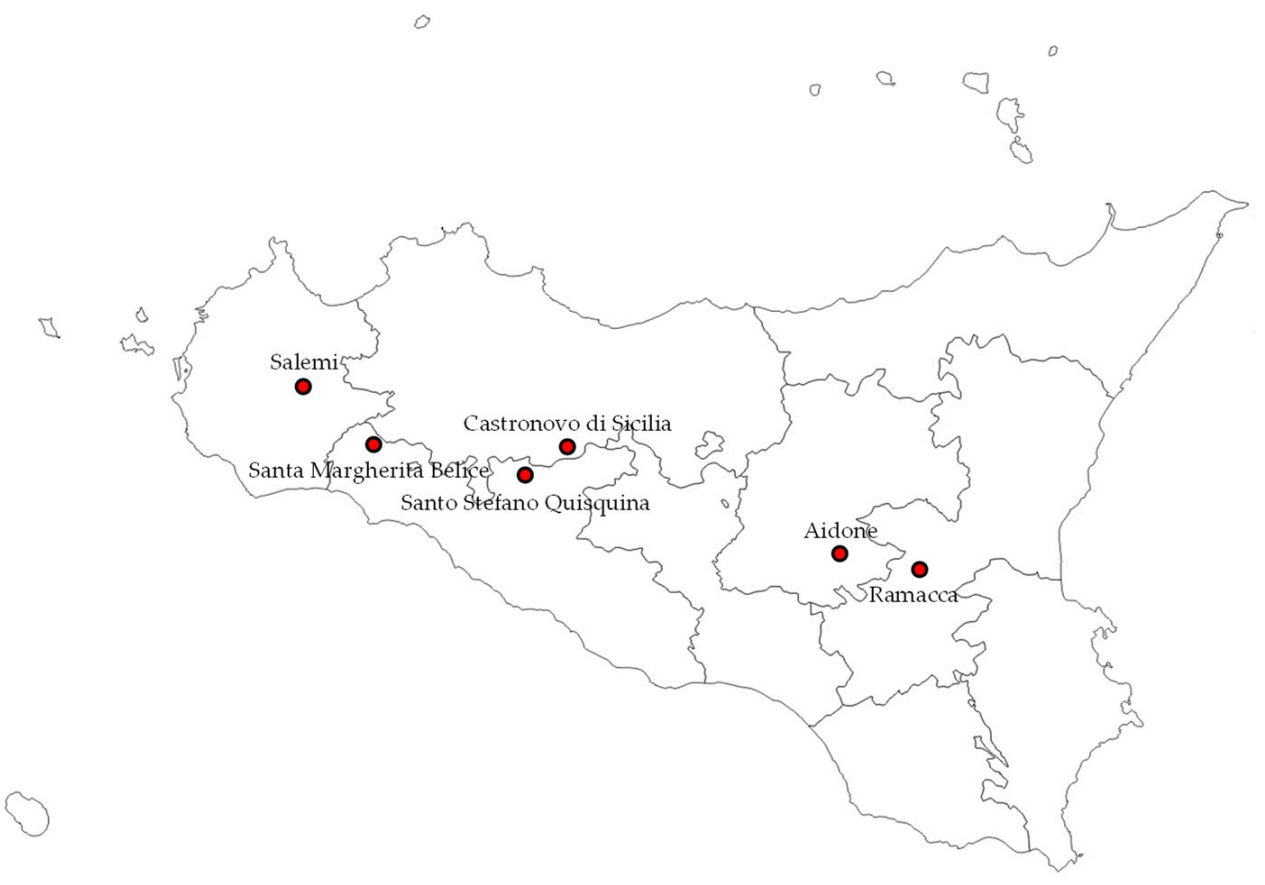

Figure 7. Location of the dairy factories producing PDO Pecorino Siciliano cheese.

The production of the cheeses in each factory was performed from the bulk milk after its contact with the wooden vat surface and then transferred into two plastic vats (Figure 8). The control cheeses were processed without LAB inoculums, while the experimental cheeses were inoculated with the mixed starter/non-starter LAB culture. Both cheese productions followed PDO Pecorino Siciliano cheese protocol, and the final cheeses were ripened for five months as for previous investigations. 


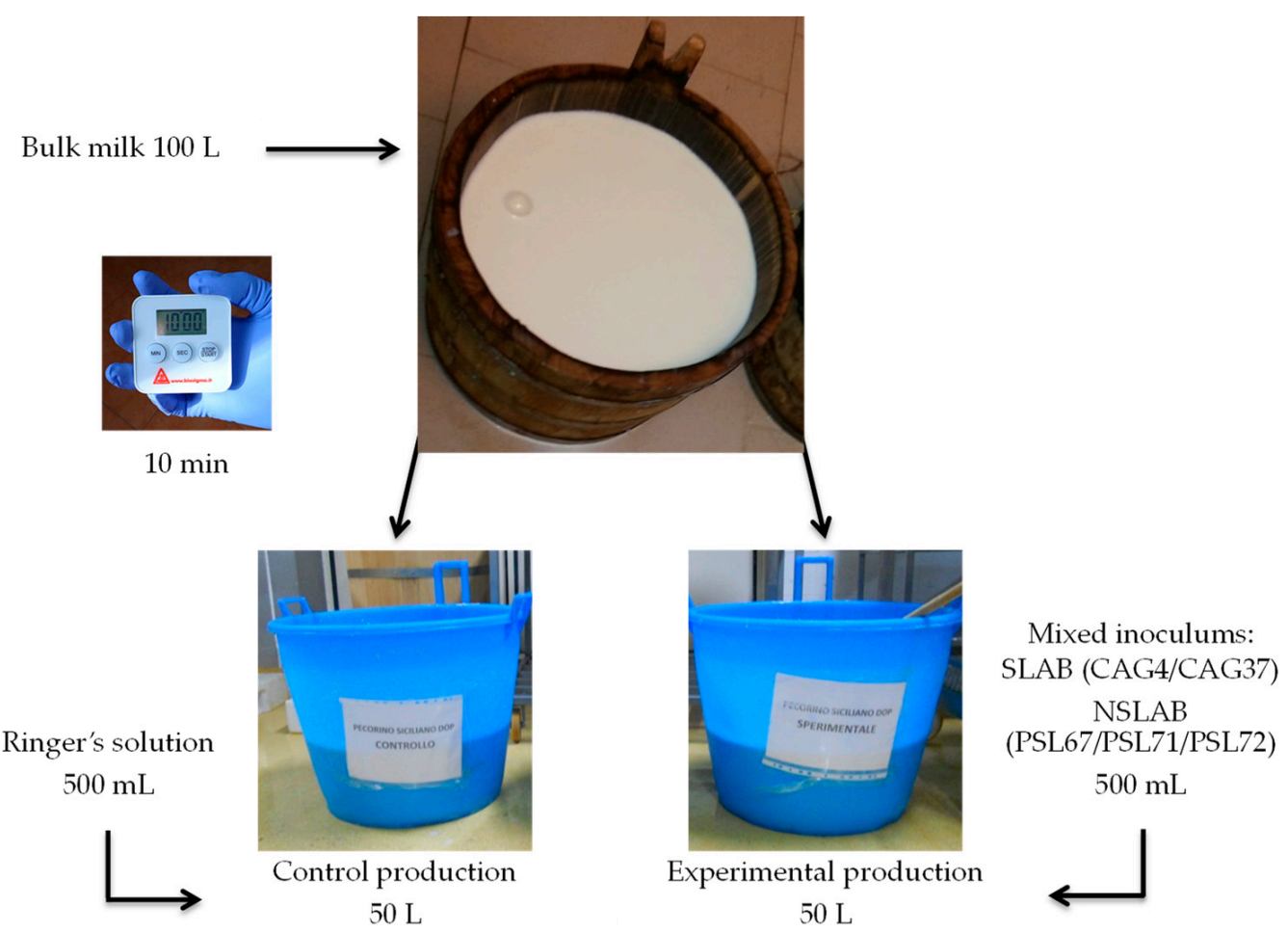

Figure 8. Working plan for PDO Pecorino Siciliano cheese production applied to test the starter/nonstarter LAB inoculums at a large scale level.

In general, the level of $\mathrm{LAB}$ cocci in the wooden vat biofilms was at higher levels than those of LAB rods. Regarding the bulk milks, they showed similar levels for LAB cocci and total mesophilic counts, thus, LAB dominated the microbial community of all raw milks processed into cheese. The cheese-making parameters were particularly variable among the six dairy factories, but all curds of the trials with selected LAB addition displayed a faster $\mathrm{pH}$ drop than control curds. The levels of LAB in ripened inoculated cheeses were higher than those registered in control cheeses. Cheese microbiotas were analyzed, applying a culture-dependent approach exclusively. The authors also performed a polymorphic profile recognition (by randomly amplified polymorphic DNA analysis) of the bacterial isolates from the agar plates at the highest cell suspension dilutions showing the dominance of the inoculated LAB over the vat $\mathrm{LAB}$ and those indigenous of milk. Regarding the undesired bacterial groups, coagulase-positive staphylococci were statistically different among the factories, members of the Enterobacteriaceae family were at low levels, while pseudomonads were below the detection limit.

The microbial stabilization of PDO Pecorino Siciliano cheese production through the addition of the selected starter/non-starter LAB was better investigated by a cultureindependent approach based on MiSeq Illumina technology by Gaglio et al. [75]. Cheese microbiota analysis showed that all control cheeses were dominated by streptococci and lactobacilli, while the cheeses processed adding the selected LAB were characterized by dominant levels of streptococci, lactobacilli, and lactococci (Figure 9). In particular, in addition to the LAB species inoculated, this approach also revealed the presence of $L t$. casei (formerly Lactobacillus zeae) in all cheeses, L. brevis and Ln. mesenteroides only in some factories in both control and inoculated cheeses. The selected LAB culture determined a slight increase in the levels of enterococci. 


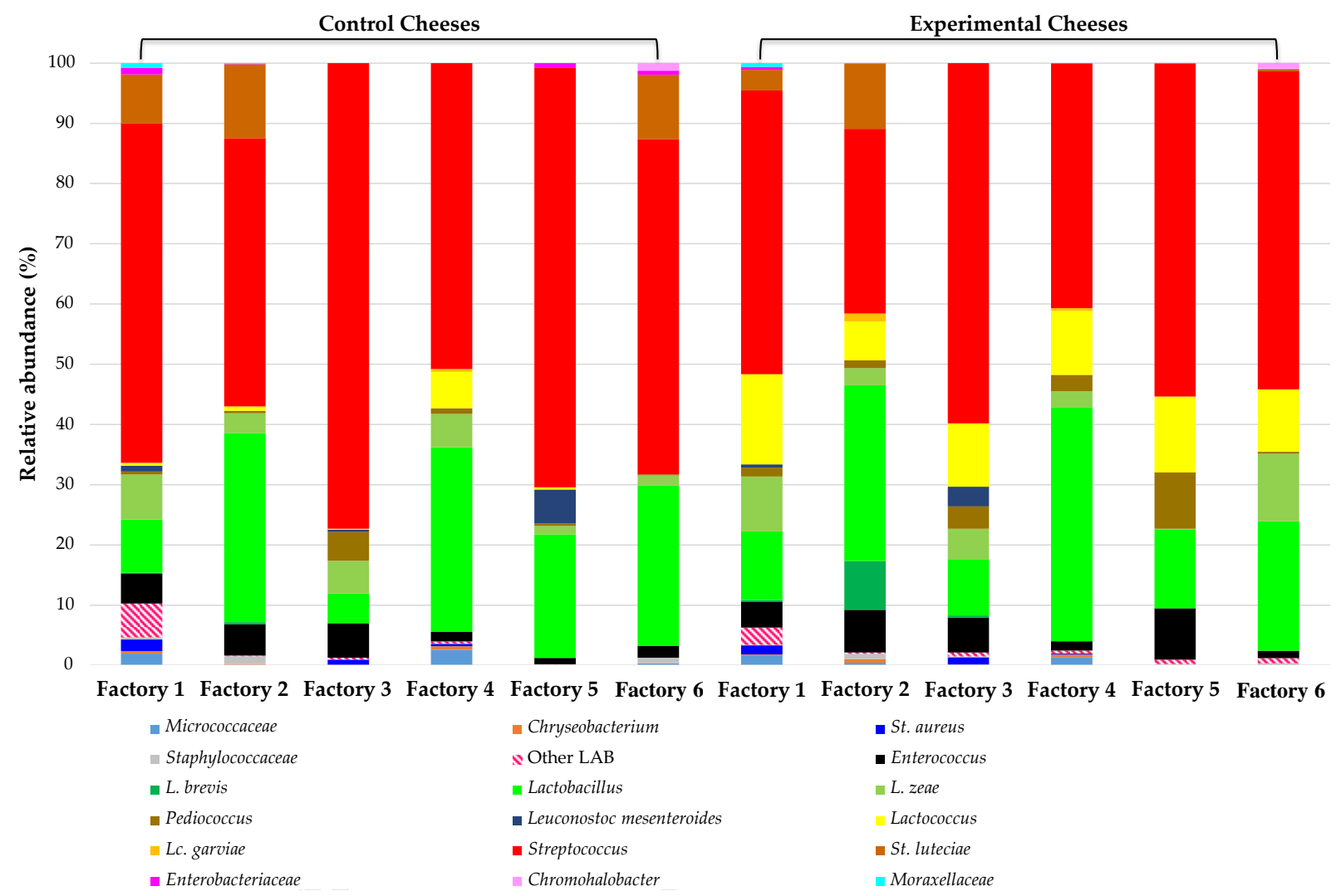

Figure 9. Relative abundances (\%) of bacteria identified by MiSeq Illumina in control and experimental PDO Pecorino Siciliano cheeses. Adapted from Gaglio et al. [70].

The presence of Staphylococcus spp. in control and experimental cheeses of three factories indicated that even after the addition of selected LAB, some cheeses may be characterized by the presence of pathogenic species and that milk hygiene is important for the safety of the final cheeses. Other minor groups including Chryseobacterium, Chromohalobacter, Micrococcaceae, and Moraxellaceae were also detected.

The final cheeses were analyzed for the chemical composition. The addition of the selected LAB did not affect cheese fatty acids (FA), mainly represented by saturated fatty acids like palmitic and myristic acids. The ratio between saturated FA and unsaturated FA, in particular oleic acid, for control and selected LAB added cheeses were almost superimposable (2.31 and 2.29, respectively). Regarding the volatile organic compound composition of the cheeses, their profiles were composed of alkanes, aldehydes, terpenes, esters, acids, ketones, and benzene. The cheeses inoculated with the selected LAB were different from those of the control cheeses only for butanoic acid, but the factories where the cheeses were produced impacted differently the presence of hexane and hexanoic acid ethyl ester that was generated at higher concentrations from the control cheeses [75]. The addition of the starter/non-starter $\mathrm{LAB}$ addition impacted the final $\mathrm{pH}$ of the ripened cheeses that was 0.1 points lower than the average value registered for the control cheeses. Specifically, the final $\mathrm{pH}$ of control cheeses was 5.76, while that of LAB added cheeses was 5.66. This finding could be of relevance in the practice of producing cheeses from raw milk. Even though 0.1 points $\mathrm{pH}$ does not strongly impact the acidity perception by consumers, a lower $\mathrm{pH}$ of the curd due to the addition of the starter culture rather than non-starter LAB exerts a stressing effect on the undesired microorganisms present in raw milk retarding or inhibiting their development. Some differences regarding cheese yield, water activity $\left(\mathrm{a}_{\mathrm{w}}\right)$, ash content, and salt percentage were registered among factories. In particular, cheese yield $\%$ and $\mathrm{a}_{\mathrm{w}}$ was higher for the control cheeses, while ash $\%$ on dry matter and salt $\%$ were higher in the cheeses added with the selected LAB [74]. 
The same cheeses were evaluated by 10 expert panelists who scored 21 descriptive attributes, including aroma, taste, surface structure, and texture [74]. The sensory tests evidenced how the addition of LAB influenced color, eye formation, uniformity of structure, and unpleasant taste. The panelists detected fewer eyes in the cheeses produced by adding the selected LAB while a higher presence of unpleasant taste was scored for the control cheeses. Furthermore, a triangle test indicated the highest preference for the cheeses produced with the addition of the LAB inoculums. Although the selected LAB determined a lowering of $\mathrm{pH}$, they did not generate an overproduction of organic acids excluding that they negatively impacted the overall assessment of the cheeses.

\section{Conclusions and Future Perspectives}

Future Perspectives

Cheese is one of the foods that are undergoing a negative impact among consumers due to their fat content and low presence of active compounds. However, very recently, cheeses are being rediscovered as foods with functional properties, in particular, when ingredients with bioactive compounds are added. From this perspective, the current research is focusing on the incorporation of several ingredients, mainly by-products rich in polyphenols and other antioxidant molecules [76]. Our research group is preparing works on the incorporation of grape pomace wastes and aromatic herbs in Pecorino Siciliano cheeses for which LAB resistant to plant polyphenols have been selected ad hoc [77-79]. Furthermore, Pecorino Siciliano cheese was evaluated as a promising matrix to deliver probiotic cultures [80], opening new routes for production and commercialization of this traditional cheese.

\section{Conclusions}

The quality of cheese productions carried out without the addition of starter cultures is quite unpredictable. In order to stabilize the characteristics of these cheeses and to preserve the typical organoleptic notes avoiding the flattening of the sensory profile of the final products, the application of commercial starter cultures is not advisable [81]. The development of starter and secondary adjunct (non-starter) cultures from autochthonous $\mathrm{LAB}$ has been reported as a winning strategy to maintain cheese typicality. Autochthonous $\mathrm{LAB}$ are those isolated from the production environment, associated to the local raw materials, and adapted to the traditional process technology [7]. The studies conducted on PDO Pecorino Siciliano cheese showed that the wooden vats used for milk collection and curdling are a primary source of useful LAB, starter cultures selected from autochthonous populations safeguard the typicality of the cheese with little modifications of the traditional manufacture technology, their application in combination with non-starter LAB determines their dominance over milk LAB and controls the development of spoilage and potential pathogenic species. These investigations also indicated that the final cheese safety does not depend exclusively on raw milk, but it is rather a consequence of several technological and microbiological factors occurring during production. Specifically, the addition of the selected mixed culture composed of Lc. lactis subsp. lactis, E. faecalis, Lc. garviae, and S. gallolyticus subsp. macedonicus at a large scale level among several dairy factories gathered into PDO Pecorino Siciliano cheese consortium was able to determine rapid curd acidification and to activate mechanisms of antagonism for the control of undesired microorganisms. This strategy provided useful evidence to preserve the identity of typical cheeses and to improve food security. However, the cooking step undoubtedly represents a key factor for the final safety of raw milk cheeses. From this perspective, the possible interaction among the cooking process, starter selection, and reduction of pathogenic and spoilage bacteria still needs to be investigated for PDO Pecorino Siciliano cheese.

Author Contributions: Conceptualization, L.S.; data curation, R.G.; writing-original draft preparation, R.G., M.T., L.S.; writing-review and editing, L.S.; project administration, M.T.; All authors have read and agreed to the published version of the manuscript. 
Funding: This work was supported by AGER 2 Project, grant no. 2017-1144.

Institutional Review Board Statement: Not applicable.

Informed Consent Statement: Not applicable.

Data Availability Statement: All data included in this study are available upon request by contacting the corresponding author.

Conflicts of Interest: The authors declare that they have no conflict of interest.

\section{References}

1. Gobbetti, M.; Neviani, E.; Fox, P. The Cheeses of Italy: Science and Technology; Springer: New York, NY, USA, 2018.

2. Osservatorio sull'Economia del Sistema Agro Alimentare della Sicilia (OEASAAS) I Formaggi Storici di Nicchia in Sicilia: Aspetti produttivi e di mercato; CORERAS Consorzio Regionale per la Ricerca Applicata e la Sperimentazione: Palermo, Italy, 2007.

3. Ricci, M. La scoperta degli archeologi siciliani: A Troina si produceva formaggio oltre 5000 anni fa. 2017. Available online: http:/ / www.cronachedigusto.it/archiviodal-05042011/325-scenari/21156-la-scoperta-degli-archeologi-siciliani-a-troinasi-produceva-formaggio-oltre-5000-anni-fa.html (accessed on 31 December 2020). (In Italian).

4. Bruni, A. Enciclopedia Agraria; Marghieri and Pellerano: Naples, Italy, 1859. (In Italian)

5. De Caprariis, T. Tipi di Formaggi Meridionali; Premiato Stabilimento Tipografia Cavaliere Priore G.M.: Naples, Italy, 1912. (In Italian)

6. Todaro, M.; Francesca, N.; Reale, S.; Moschetti, G.; Vitale, F.; Settanni, L. Effect of different salting technologies on the chemical and microbiological characteristics of PDO Pecorino Siciliano cheese. Eur. Food Res. Technol. 2011, 233, 931-940. [CrossRef]

7. Settanni, L.; Moschetti, G. New trends in technology and identity of traditional dairy and fermented meat production processes. Trends Food Sci. Technol. 2014, 37, 51-58. [CrossRef]

8. Regulation (EU) No 1151/2012 of the European Parliament and of the Council of 21 November 2012 on quality schemes for agricultural products and foodstuffs. Off. J. Eur. Union 2012, 343, 1-29.

9. Cruciata, M.; Gaglio, R.; Todaro, M.; Settanni, L. Ecology of Vastedda della valle del Belìce cheeses: A review and recent findings to stabilize the traditional production. Food Rev. Int. 2019, 35, 90-103. [CrossRef]

10. Settanni, L. Attrezzi di legno per produzioni casearie tipiche siciliane. Il Latte 2018, 5, 46-49. (In Italian)

11. Settanni, L.; Moschetti, G. Non-starter lactic acid bacteria used to improve cheese quality and provide health benefits. Food Microbiol. 2010, 27, 691-697. [CrossRef] [PubMed]

12. Johnson, E.A.; Nelson, J.H.; Johnson, M. Microbiological safety of cheese made from heat treated milk. Part I: Executive summary, introduction and history. J. Food Prot. 1990, 53, 441-452. [CrossRef]

13. Decree, Italian Presidential. Riconoscimento delle denominazioni circa i metodi di lavorazione, caratteristiche merceologiche e zone di produzione dei formaggi. Off. Gaz. Ital. Repub. 1955, 295.

14. Betta, P.; Cantarelli, F. Dal Mito Alla Storia il Pecorino Siciliano; CORERAS Consorzio Regionale per la Ricerca Applicata e la Sperimentazione: Palermo, Italy, 2000.

15. McSweeney, P.L.; Ottogalli, G.; Fox, P.F. Diversity and classification of cheese varieties: An overview. In Cheese; Academic Press: Gaithersburg, MD, USA, 2017; pp. 781-808.

16. Settanni, L.; Gaglio, R.; Guarcello, R.; Francesca, N.; Carpino, S.; Sannino, C.; Todaro, M. Selected lactic acid bacteria as a hurdle to the microbial spoilage of cheese: Application on a traditional raw ewes' milk cheese. Int. Dairy J. 2013, 32, 126-132. [CrossRef]

17. Settanni, L.; Cruciata, M.; Guarcello, R.; Francesca, N.; Moschetti, G.; La Carrubba, V.; Gaglio, R. Valorisation of dairy wastes through kefir grain production. Waste Biomass Valor. 2020, 11, 3979-3985. [CrossRef]

18. Scatassa, M.L.; Gaglio, R.; Macaluso, G.; Francesca, N.; Randazzo, W.; Cardamone, C.; Di Grigoli, A.; Moschetti, G.; Settanni, L. Transfer, composition and technological characterization of the lactic acid bacterial populations of the wooden vats used to produce traditional stretched cheeses. Food Microbiol. 2015, 52, 31-41. [CrossRef] [PubMed]

19. Cruciata, M.; Gaglio, R.; Scatassa, M.L.; Sala, G.; Cardamone, C.; Palmeri, M.; Moschetti, G.; La Mantia, T.; Settanni, L. Formation and characterization of early bacterial biofilms on different wood typologies applied in dairy production. Appl. Environ. Microbiol. 2018, 84, e02107-e02117. [CrossRef]

20. Gaglio, R.; Cruciata, M.; Scatassa, M.L.; Tolone, M.; Mancuso, I.; Cardamone, C.; Corona, O.; Todaro, M.; Settanni, L. Influence of the early bacterial biofilms developed on vats made with seven wood types on PDO Vastedda della valle del Belice cheese characteristics. Int. J. Food Microbiol. 2019, 291, 91-103. [CrossRef]

21. Regulation (EC) No 1935/2004 of the European Parliament and of the Council of 27 October 2004 on materials and articles intended to come into contact with food and repealing Directives 80/590/EEC and 89/109/EEC. Off. J. Eur. Union 2004, 338, 4-17.

22. Aviat, F.; Gerhards, C.; Rodriguez-Jerez, J.-J.; Michel, V.; Le Bayon, I.; Ismail, R.; Federighi, M. Microbial safety of wood in contact with food: A review. Compr. Rev. Food Sci. Food Saf. 2016, 15, 491-505. [CrossRef]

23. Commission Regulation (EC) No 2074/2005 of 5 December 2005 laying down implementing measures for certain products under Regulation (EC) No 853/2004 of the European Parliament and of the Council and for the organisation of official controls under Regulation (EC) No 854/2004 of the European Parliament and of the Council and Regulation (EC) No 882/2004 of the European Parliament and of the Council, derogating from Regulation (EC) No 852/2004 of the European Parliament and of the Council and amending Regulations (EC) No 853/2004 and (EC) No 854/2004. Off. J. Eur. Union 2005, 338, 27-59. 
24. Licitra, G.; Ogier, J.C.; Parayre, S.; Pediliggieri, C.; Carnemolla, T.M.; Falentin, H.; Madec, M.N.; Carpino, S.; Lortal, S. Variability of the bacterial biofilms of the "tina" wood vat used in the Ragusano cheese making process. Appl. Environ. Microbiol. 2007, 73, 6980-6987. [CrossRef] [PubMed]

25. Lortal, S.; Licitra, G.; Valence, F. Wooden tools: Reservoirs of microbial biodiversity in traditional cheese making. Microbiol. Spectr. 2014, 2, 167-176.

26. Settanni, L.; Di Grigoli, A.; Tornambè, G.; Bellina, V.; Francesca, N.; Moschetti, G.; Bonanno, A. Persistence of wild Streptococcus thermophilus strains on wooden vat and during the manufacture of a Caciocavallo type cheese. Int. J. Food Microbiol. 2012, 155, 73-81. [CrossRef] [PubMed]

27. Carpino, S.; Randazzo, C.L.; Pino, A.; Russo, N.; Rapisarda, T.; Belvedere, G.; Caggia, C. Influence of PDO Ragusano cheese biofilm microbiota on flavour compounds formation. Food Microbiol. 2017, 61, 126-135. [CrossRef]

28. Di Grigoli, A.; Francesca, N.; Gaglio, R.; Guarrasi, V.; Moschetti, M.; Scatassa, M.-L.; Settanni, L.; Bonanno, A. The influence of the wooden equipment employed for cheese manufacture on the characteristics of a traditional stretched cheese during ripening. Int. J. Food Microbiol. 2015, 46, 81-91. [CrossRef]

29. Guarrasi, V.; Sannino, C.; Moschetti, M.; Bonanno, A.; Di Grigoli, A.; Settanni, L. The individual contribution of starter and non starter lactic acid bacteria to the volatile organic compound composition of Caciocavallo Palermitano cheese. Int. J. Food Microbiol. 2017, 259, 35-42. [CrossRef]

30. Didienne, R.; Defargues, C.; Callon, C.; Meylheuc, T.; Hulin, S.; Montel, M.C. Characteristics of microbial biofilm on wooden vats ('gerles') in PDO Salers cheese. Int. J. Food Microbiol. 2012, 156, 91-101. [CrossRef]

31. Gaglio, R.; Cruciata, M.; Di Gerlando, R.; Scatassa, M.L.; Cardamone, C.; Mancuso, I.; Sardina, M.T.; Moschetti, G.; Portolano, B.; Settanni, L. Microbial activation of wooden vats used for traditional cheese production and evolution of the neo-formed biofilms. Appl. Environ. Microbiol. 2016, 82, 585-595. [CrossRef]

32. Azeredo, J.; Azevedo, N.-F.; Briande, R.; Cerca, N.; Coenye, T.; Costa, A.-R.; Desvaux, M.; Di Bonaventura, G.; Hèbraud, M.; Jaglic, Z. Critical review on biofilm methods. Crit. Rev. Microbiol. 2017, 43, 313-351. [CrossRef] [PubMed]

33. Vert, M.; Doi, Y.; Hellwich, K.-H.; Hess, M.; Hodge, P.; Kubisa, P.; Rinaudo, M.; Schué, F. Terminology for biorelated polymers and applications (IUPAC Recommendations 2012). Pure Appl. Chem. 2012, 84, 377-410. [CrossRef]

34. Scatassa, M.L.; Cardamone, C.; Miraglia, V.; Lazzara, F.; Fiorenza, G.; Macaluso, G.; Arcuri, L.; Settanni, L.; Mancuso, I. Characterisation of the microflora contaminating wooden vats used for traditional Sicilian cheese production. Ital. J. Food Saf. 2015, 4509, 36-39. [CrossRef] [PubMed]

35. Zheng, J.; Wittouck, S.; Salvetti, E.; Franz, C.M.; Harris, H.M.; Mattarelli, P.; O’Toole, P.W.; Pot, B.; Vandamme, P.; Walter, J.; et al. A taxonomic note on the genus Lactobacillus: Description of 23 novel genera, emended description of the genus Lactobacillus Beijerinck 1901, and union of Lactobacillaceae and Leuconostocaceae. Int. J. Syst. Evol. Microbiol. 2020, 70, 2782-2858. [CrossRef]

36. Commission Regulation (EC) No 2073/2005 of 15 November 2005 on microbiological criteria for foodstuffs. Off. J. Eur. Union 2005, 338, 1-26.

37. Lortal, S.; Di Blasi, A.; Madec, M.-N.; Pediliggieri, C.; Tuminello, L.; Tangury, G.; Fauquant, J.; Lecuona, Y.; Campo, P.; Carpino, S.; et al. Tina wooden vat biofilm. A safe and highly efficient lactic acid bacteria delivering system in PDO Ragusano cheese making. Int. J. Food Microbiol. 2009, 132, 1-8. [CrossRef] [PubMed]

38. Corsetti, A.; Settanni, L.; Braga, T.M.; Lopes, M.; de Fatima Silva Lopes, M.; Suzzi, G. An investigation on the bacteriocinogenic potential of lactic acid bacteria associated with wheat (Triticum durum) kernels and non-conventional flours. Lwt-Food Sci. Technol. 2008, 41, 1173-1182. [CrossRef]

39. Vernile, A.; Spano, G.; Beresford, T.P.; Fox, P.F.; Beneduce, L.; Massa, S. Microbial study of Pecorino Siciliano cheese throughout ripening. Milchwissenschaft 2006, 61, 169-173.

40. Vernile, A.; Giammanco, G.; Spano, G.; Beresford, T.P.; Fox, P.F.; Massa, S. Genotypic characterization of lactic acid bacteria isolated from traditional Pecorino Siciliano cheese. Dairy Sci. Technol. 2008, 88, 619-629. [CrossRef]

41. Randazzo, C.L.; Vaughan, E.E.; Caggia, C. Artisanal and experimental Pecorino Siciliano cheese: Microbial dynamics during manufacture assessed by culturing and PCR-DGGE analyses. Int. J. Food Microbiol. 2008, 109, 1-8. [CrossRef] [PubMed]

42. Caggia, C.; De Angelis, M.; Pitino, I.; Randazzo, C.L. Probiotic features of Lactobacillus strains isolated from Ragusano and Pecorino Siciliano cheeses. Food Microbiol. 2015, 50, 109-117. [CrossRef] [PubMed]

43. Monfredini, L.; Settanni, L.; Poznanski, E.; Cavazza, A.; Franciosi, E. The spatial distribution of bacteria in grana-cheese during ripening. Syst. Appl. Microbiol. 2012, 35, 54-63. [CrossRef]

44. Gaglio, R.; Todaro, M.; Scatassa, M.L.; Franciosi, E.; Corona, O.; Mancuso, I.; Di Gerlando, R.; Cardamone, C.; Settanni, L. Transformation of raw ewes' milk applying "Grana" type pressed cheese technology: Development of extra-hard "Gran Ovino" cheese. Int. J. Food Microbiol. 2019, 307, 108277. [CrossRef]

45. Settanni, L.; Franciosi, E.; Cavazza, A.; Cocconcelli, P.-S.; Poznanski, E. Extension of Tosèla cheese shelf-life using non-starter lactic acid bacteria. Food Microbiol. 2011, 28, 883-890. [CrossRef]

46. Fernández, E.; Alegría, Á.; Delgado, S.; Mayo, B. Phenotypic, genetic and technological characterization of Lactococcus garvieae strains isolated from a raw milk cheese. Int. Dairy J. 2010, 20, 142-148. [CrossRef]

47. Foulquié Moreno, M.-R.; Sarantinopoulos, P.; Tsakalidou, E.; De Vuyst, L. The role and application of enterococci in food and health. Int. J. Food Microbiol. 2006, 106, 1-24. [CrossRef] [PubMed] 
48. Gaglio, R.; Couto, N.; Marques, C.; de Fatima Silva Lopes, M.; Moschetti, G.; Pomba, C.; Settanni, L. Evaluation of antimicrobial resistance and virulence of enterococci from equipment surfaces, raw materials and traditional cheeses. Int. J. Food Microbiol. 2016, 236, 107-114. [CrossRef] [PubMed]

49. Franciosi, E.; Settanni, L.; Cologna, N.; Cavazza, A.; Poznanski, E. Microbial analysis of raw cows' milk used for cheese-making: Influence of storage treatments on microbial composition and other technological traits. World J. Microbiol. Biotechnol. 2011, 27, 171-180. [CrossRef]

50. Franciosi, E.; Settanni, L.; Cavazza, A.; Poznanski, E. Biodiversity and technological potential of wild lactic acid bacteria from raw cows' milk. Int. Dairy. J. 2009, 19, 3-11. [CrossRef]

51. Cruciata, M.; Sannino, C.; Ercolini, D.; Scatassa, M.-L.; De Filippis, F.; Mancuso, I.; La Storia, A.; Moschetti, G.; Settanni, L. Animal rennets as sources of dairy lactic acid bacteria. Appl. Environ. Microbiol. 2014, 80, 2050-2061. [CrossRef]

52. Settanni, L.; Guarcello, R.; Gaglio, R.; Francesca, N.; Aleo, A.; Felis, G.E.; Moschetti, G. Production, stability, gene sequencing and in situ anti-Listeria activity of mundticin KS expressed by three Enterococcus mundtii strains. Food Contr. 2014, 35, 311-322. [CrossRef]

53. Russo, N.; Caggia, C.; Pino, A.; Coque, T.M.; Arioli, S.; Randazzo, C.L. Enterococcus spp. in Ragusano PDO and Pecorino Siciliano cheese types: A snapshot of their antibiotic resistance distribution. Food Chem. Toxicol. 2018, 120, 277-286. [CrossRef] [PubMed]

54. Pisano, M.B.; Fadda, M.E.; Deplano, M.; Corda, A.; Cosentino, S. Microbiological and chemical characterization of Fiore Sardo, a traditional Sardinian cheese made from ewe's milk. Int. J. Dairy Technol. 2006, 59, 171-179. [CrossRef]

55. Prodromou, K.; Thasitou, P.; Haritonidou, E.; Tzanetakis, N.; Litopoulou-Tzanetaki, E. Microbiology of "Orinotyri”, a ewe's milk cheese from the Greek mountains. Food Microbiol. 2001, 18, 319-328. [CrossRef]

56. Tavaria, F.K.; Malcata, F.X. On the microbiology of Serra da Estrela cheese: Geographical and chronological considerations. Food Microbiol. 2000, 17, 293-304. [CrossRef]

57. Marino, M.; Maifreni, M.; Moret, S.; Rondinini, G. The capacity of Enterobacteriaceae species to produce biogenic amines in cheese. Lett. Appl. Microbiol. 2000, 31, 169-173. [CrossRef]

58. Macedo, A.C.; Malcata, F.X.; Hogg, T.A. Microbiological profile in Serra ewes' cheese during ripening. J. Appl. Bacteriol. 1995, 79, 1-11. [CrossRef]

59. Högenauer, C.; Langner, C.; Beubler, E.; Lippe, I.T.; Schicho, R.; Gorkiewicz, G.; Krause, R.; Gerstgrasser, N.; Krejs, G.J.; Hinterleitner, T.A. Klebsiella oxytoca as a causative organism of antibiotic-associated hemorrhagic colitis. N. Engl. J. Med. 2006, 355, 2418-2426. [CrossRef] [PubMed]

60. Choudhuri, I.; Khanra, K.; Maity, P.; Patra, A.; Maity, G.N.; Pati, B.R.; Nag, A.; Mondal, S.; Bhattacharyya, N. Structure and biological properties of exopolysaccharide isolated from Citrobacter freundii. Int. J. Biol. Macromol. 2021, 168, 537-549. [CrossRef] [PubMed]

61. Jang, J.; Hur, H.G.; Sadowsky, M.J.; Byappanahalli, M.N.; Yan, T.; Ishii, S. Environmental Escherichia coli: Ecology and public health implications-A review. J. Appl. Microbiol. 2017, 123, 570-581. [CrossRef]

62. Martuscelli, M.; Gardini, F.; Torriani, S.; Mastrocola, D.; Serio, A.; Chaves-López, C.; Schirone, M.; Suzzi, G. Production of biogenic amines during the ripening of Pecorino Abruzzese cheese. Int. Dairy J. 2005, 15, 571-578. [CrossRef]

63. Hayes, P.R. Food Microbiology and Hygiene; Chapman \& Hall: London, UK, 1995.

64. Giammanco, G.M.; Pepe, A.; Aleo, A.; D’Agostino, V.; Milone, S.; Mammina, C. Microbiological quality of Pecorino Siciliano“ primosale" cheese on retail sale in the street markets of Palermo, Italy. New Microbiol. 2011, 34, 179-185.

65. Cardamone, C.; Cirlincione, F.; Gaglio, R.; Puccio, V.; Daidone, F.; Sciortino, S.; Mancuso, I.; Scatassa, M.L. Behavior of four main dairy pathogenic bacteria during manufacturing and ripening of Pecorino Siciliano cheese. J. Food Qual. Haz. Contr. 2020, 7, 27-35. [CrossRef]

66. Guarcello, R.; Diviccaro, A.; Barbera, M.; Giancippoli, E.; Settanni, L.; Minervini, F.; Moschetti, G.; Gobbetti, M. A survey on the main technology, biochemical and microbiological features influencing the concentration of biogenic amines of twenty Apulian and Sicilian (Southern Italy) cheeses. Int. Dairy J. 2015, 43, 61-69. [CrossRef]

67. Silla-Santos, M.-H. Biogenic amines: Their importance in food. Int. J. Food Microbiol. 1996, 29, 213-221. [CrossRef]

68. Guarcello, R.; De Angelis, M.; Settanni, L.; Formiglio, S.; Gaglio, R.; Minervini, F.; Moschetti, G.; Gobbetti, M. Selection of amine oxidizing dairy lactic acid bacteria: Enzyme and gene involved in the decrease of biogenic amines. Appl. Environ. Microbiol. 2016, 82, 6870-6880. [CrossRef]

69. Regulation (EC) No 853/2004 of the European Parliament and of the Council of 29 April 2004 laying down specific hygiene rules for food of animal origin. Off. J. Eur. Union 2004, 45, 247-260.

70. Mucchetti, G.; Neviani, E. Microbiologia e tecnologia lattierocasearia. Qualità e sicurezza; Tecniche Nuove: Milan, Italy, 2006. (In Italian)

71. Donnelly, C.W. Growth and survival of microbial pathogens in cheese. In Cheese: Chemistry, Physics and Microbiology; Chapman \& Hall: London, UK, 2004; pp. 541-560.

72. Macedo, A.C.; Tavares, T.G.; Malcata, F.X. Influence of native lactic acid bacteria on the microbiological, biochemical and sensory profiles of Serra da Estrela cheese. Food Microbiol. 2004, 21, 233-240. [CrossRef]

73. Muruzović, M.Ž.; Mladenović, K.G.; Žugić-Petrović, T.D.; Čomić, L.R. Characterization of lactic acid bacteria isolated from traditionally made Serbian Cheese and evaluation of their antagonistic potential against Enterobacteriaceae. J. Food Process. Preserv. 2018, 42, e13577. [CrossRef] 
74. Guarcello, R.; Carpino, S.; Gaglio, R.; Pino, A.; Rapisarda, T.; Caggia, C.; Marino, G.; Randazzo, C.L.; Settanni, L.; Todaro, M. A large factory-scale application of selected autochthonous lactic acid bacteria for PDO Pecorino Siciliano cheese production. Food Microbiol. 2016, 59, 66-75. [CrossRef] [PubMed]

75. Gaglio, R.; Franciosi, E.; Todaro, A.; Guarcello, R.; Alfeo, V.; Randazzo, C.L.; Settanni, L.; Todaro, M. Addition of selected starter/non-starter lactic acid bacterial inoculums to stabilise PDO Pecorino Siciliano cheese production. Food Res. Int. 2020, 136, 109335. [CrossRef]

76. Marchiani, R.; Bertolino, M.; Ghirardello, D.; McSweeney, P.L.; Zeppa, G. Physicochemical and nutritional qualities of grape pomace powder-fortified semi-hard cheeses. J. Food Sci. Technol. 2016, 53, 1585-1596. [CrossRef] [PubMed]

77. Barbaccia, P.; Francesca, N.; Gerlando, R.D.; Busetta, G.; Moschetti, G.; Gaglio, R.; Settanni, L. Biodiversity and dairy traits of indigenous milk lactic acid bacteria grown in presence of the main grape polyphenols. FEMS Microbiol. Lett. 2020, 367, fnaa066. [CrossRef] [PubMed]

78. Gaglio, R.; Catania, P.; Orlando, S.; Vallone, M.; Moschetti, G.; Settanni, L. Biodiversity and dairy traits of lactic acid bacteria from foliage of aromatic plants before and after dehydration process monitored by a smart sensors system. FEMS Microbiol. Lett. 2020, 367, fnaa071. [CrossRef]

79. Gaglio, R.; Restivo, I.; Barbera, M.; Barbaccia, P.; Ponte, M.; Tesoriere, L.; Bonanno, A.; Attanzio, A.; Di Grigoli, A.; Francesca, N.; et al. Effect on the antioxidant, lipoperoxyl radical scavenger capacity, nutritional, sensory and microbiological traits of an ovine stretched cheese produced with grape pomace powder addition. Antioxidants 2021. (Accepted).

80. Pino, A.; Van Hoorde, K.; Pitino, I.; Russo, N.; Carpino, S.; Caggia, C.; Randazzo, C.L. Survival of potential probiotic lactobacilli used as adjunct cultures on Pecorino Siciliano cheese ripening and passage through the gastrointestinal tract of healthy volunteers. Int. J. Food Microbiol. 2017, 252, 42-52. [CrossRef] [PubMed]

81. Leboš Pavunc, A.; Beganović, J.; Kos, B.; Uroić, K.; Blažić, M.; Šušković, J. Characterization and application of autochthonous starter cultures for fresh cheese production. Food Technol. Biotechnol. 2012, 50, 141-151. 